\title{
GMR
}

\section{Single nucleotide polymorphisms in the CNTNAP2 gene in Brazilian patients with autistic spectrum disorder}

\author{
P.P. Nascimento ${ }^{1}$, A.L. Bossolani-Martins ${ }^{2}$, D.B.A. Rosan', L.C. Mattos ${ }^{3}$, \\ C. Brandão-Mattos ${ }^{3}$ and A.C. Fett-Conte ${ }^{3}$ \\ 1'Departamento de Biologia, Instituto de Biociências, Letras e Ciências Exatas, \\ São José do Rio Preto, SP, Brasil \\ ${ }^{2}$ Universidade Federal de Mato Grosso do Sul, Campus de Paranaíba, \\ Paranaíba, SP, Brasil \\ ${ }^{3}$ Departamento de Biologia Molecular, Faculdade de Medicina de São José do Rio Preto, \\ São José do Rio Preto, SP, Brasil \\ Corresponding author: P.P. Nascimento \\ E-mail: patyppn.bio@gmail.com \\ Genet. Mol. Res. 15 (1): gmr.15017422 \\ Received August 11, 2015 \\ Accepted October 23, 2015 \\ Published February 5, 2016 \\ DOI http://dx.doi.org/10.4238/gmr.15017422
}

ABSTRACT. The role of some genes and their single nucleotide polymorphisms (SNPs) as genetic contributors of complex diseases is still a topic of much investigation. Research on genes related to autism susceptibility has been somewhat challenging, but also promising. Common genomic variants of CNTNAP2 have been associated with autism, and a range of autistic phenotypes such as impaired language function, abnormal social behavior, intellectual deficiency, epilepsy, and schizophrenia have been associated with this gene. Earlier findings have suggested that SNPs in the CNTNAP2 gene may be used as genetic markers for predisposition to autism spectrum disorder (ASD). We analyzed the SNPs (rs7794745 and rs2710102) in the CNTNAP2 gene of 210 individuals with idiopathic ASD and 200 non-autistic individuals by polymerase chain reaction-restriction fragment length polymorphism. The 
results revealed higher frequency distributions statistically significant $(\mathrm{P}=$ 0.034) of the homozygous SNP rs7794745 (presumed risk genotype) in ASD patients as compared with control subjects. The results also showed an association $(\mathrm{OR}=1.802,95 \% \mathrm{Cl}=1.054-3.083, \mathrm{P}=0.042)$ between the same homozygous genotype and ASD, suggesting that it is a susceptibility factor for autism in this Brazilian population.

Key words: Autism; Caspr2; Predisposition; Genetic factors

\section{INTRODUCTION}

Autism spectrum disorder (ASD) are a set of heterogeneous neurodevelopmental conditions characterized by early-onset difficulties in the social-communication domain, repetitive behaviors, and restricted interests with varying levels of impairment throughout the development of the affected individual (Faras et al., 2010; Lauritsen, 2013). The prevalence of ASD is approximately 1:88; ASD occurs in all ethnic and social groups, with males being more predominately affected, with a ratio of 4:1 (Currenti, 2010; Chung et al., 2014; Lai et al., 2014).

Neither genetic factors nor the environmental components have been extensively characterized to allow for diagnosis and treatment of non-syndromic ASD. However, genome-wide association studies have amassed evidence suggesting the involvement of hundreds of genes and their associated genetic pathways (Loke et al., 2015). Research reveals that non-syndromic cases may have multiple genomic components, which suggests that investigations of underlying susceptibility genes in autism may be somewhat challenging (Sokolowsky et al., 2012; Poot, 2015).

The etiology of ASD is complex and can be determined in $5-25 \%$ of the cases (Devlin and Scherer, 2012; Buxbaum et al., 2014). Many proposed candidate genes act on the central nervous system, affecting neural development and synaptic activities in particular. This may lead to abnormalities in neurological development and to neurobehavioral disorders such as ASD (Perche et al., 2010; Ye et al., 2010). Genomic analysis revealed that single nucleotide polymorphisms (SNPs) in candidate genes can be associated with predisposition to these disorders and may provide possible explanations for the phenotypic variability in autism (Abrahams and Geschwind, 2008; Mefford et al., 2012).

The contactin-associated protein-like 2 (CNTNAP2) gene (MIM 604569) has been mapped onto chromosome 7q35-36, and is one of the largest genes in the human genome with 2.5 million bp. It encodes the transmembrane protein Caspr2, which is a member of the neurexin family that functions as cell adhesion molecules as well as receptors in the nervous system (Alarcón et al., 2008; Arking et al., 2008; Stein et al., 2011). This protein is localized at the juxtaparanodes of myelinated axons and may play a role in the differentiation and function of these structures. Based on genomic rearrangements and copy number variations, the CNTNAP 2 gene has been implicated in predisposition to neurodevelopmental disorders such as autism. Exome sequencing, which covers $<0.2 \%$ of the CNTNAP2 genomic DNA, has revealed numerous SNP in healthy individuals and in patients with neurodevelopmental disorders (Peñagarikano and Geschwind, 2012; Clemm von Hohenberg et al., 2013; Poot, 2015).

The SNPs rs7794745 (A/T) and rs2710102 (C/T) of the CNTNAP2 gene have been associated with childhood autism and with language impairment in non-autistic individuals (Arking et al., 2008; Scott-Van Zeeland et al., 2010; Whalley et al., 2011). Furthermore, recent structural 
imaging studies showed that healthy individuals homozygous for the presumed risk allele rs7794745 (genotype TT) show significant changes in brain regions previously reported to be altered in ASD individuals (Alarcón et al., 2008; Tan et al., 2010). However, Jonsson et al. (2014) suggested that these SNPs do not have any major influence on autistic-like traits in Swedish children.

Current literature on the frequencies of these polymorphisms in different populations and their relations with autism is still unclear. Therefore, the biological role of the CNTNAP2 gene in ASD is still a study focus area. In this context, we present the preliminary results of an investigation on the SNPs rs7794745 and rs2710102 of the CNTNAP2 gene, which has been performed for the first time in Brazilians affected with ASD.

\section{MATERIAL AND METHODS}

\section{Subjects}

The study protocol was approved by the Ethics Research Committee of the School of Medicine in São José do Rio Preto. Written informed consent was obtained from all subjects or their guardians and from control individuals.

The study involved 410 individuals; 210 idiopathic ASD (174 males and 36 females, 13.4 \pm 1.37 years old) patients were recruited into psychiatric clinics and specialized schools in São Paulo State, Brazil. ASD was diagnosed according to the DSM-5 (APA, 2013) following previously standardized criteria. All patients were evaluated for possible associated syndromes, as well as for potential environmental etiology and chromosomal abnormalities by conventional GTG-banding. Males were also tested for the FMR1 gene mutation by molecular tests. Individuals who had these alterations, were dysmorphic, or had hearing disorders were excluded from the study.

The control group included 200 healthy Brazilian individuals (137 males and 63 females; age, $34 \pm 6.2$ years) who had no psychiatric disorders and had no family history of such disorders for at least three generations or in the next generation. They were recruited among healthy blood donors from the Blood Center of São José do Rio Preto, São Paulo, Brazil.

\section{Genotyping of SNPs}

Blood was obtained from autistic probands and control individuals. Genomic DNA was extracted from whole peripheral blood samples by the Ficoll Paque method (Miller et al., 1988).

We selected two SNPs in the CNTNAP2 gene, rs7794745 and rs2710102, by in silico analysis. These SNPs were genotyped in all participants by polymerase chain reaction-restriction fragment length polymorphism (PCR-RFLP) analysis. Primer sequences and PCR-RFLP analysis are presented in Table 1. For the SNP rs2710102, PCR was carried out in a $20.0 \mu \mathrm{L}$ reaction volume containing $9.7 \mu \mathrm{L}$ ultrapure water, $2.5 \mu \mathrm{L}$ reaction buffer, $0.8 \mu \mathrm{L} \mathrm{MgCl}_{2}, 0.5 \mu \mathrm{L}$ dimethylsulfoxide (100\% DMSO), $1.0 \mu \mathrm{L} 10 \mathrm{pM}$ primer (sense and anti-sense), $2.0 \mu \mathrm{L} 1.25 \mathrm{mM} \mathrm{dNTP}, 0.2 \mu \mathrm{L}$ Taq polymerase, and $2.0 \mu \mathrm{L} 50 \mathrm{ng} / \mu \mathrm{L}$ DNA. Amplification cycles were as follows: initial denaturation at $95^{\circ}(5 \mathrm{~min})$, followed by 35 cycles at $95^{\circ} \mathrm{C}(1 \mathrm{~min}), 59^{\circ} \mathrm{C}(30 \mathrm{~s}), 72^{\circ} \mathrm{C}(30 \mathrm{~s})$, and extension at $72^{\circ} \mathrm{C}$ (5 min). An aliquot $\left(7.0 \mu \mathrm{L}\right.$ ) of the PCR product was completely digested at $37^{\circ} \mathrm{C}$ with $0.7 \mu \mathrm{L} 5 \mathrm{U} /$ $\mu \mathrm{L}$ restriction enzyme for $20 \mathrm{~min}$. The digested DNA fragments were subjected to electrophoresis on a 3\% agarose gel. The conditions used for PCR amplification of the rs7794745 SNP have been described by $\mathrm{Li}$ et al. (2010). An aliquot $(7.0 \mu \mathrm{L})$ of the PCR product was completely digested at 
$65^{\circ} \mathrm{C}$ with $0.5 \mu \mathrm{L} 5 \mathrm{U} / \mu \mathrm{L}$ of the restriction enzyme for $20 \mathrm{~min}$. Electrophoresis was performed for digested DNA fragments using a $3 \%$ agarose gel.

Table 1. Primer sequences and PCR-RFLP analysis.

\begin{tabular}{l|l|c|c|c|c}
\hline SNP & Primer sequence (5'-3') & Product (bp) & Restriction enzyme & \multicolumn{2}{c}{ Allele (bp) } \\
\hline rs 2710102 & ATGGATGGACTGACCGATTG & 198 & $\begin{array}{c}\text { Aval } \\
\text { (Eco881) }\end{array}$ & $\begin{array}{c}\text { C } \\
(43 / 155)\end{array}$ \\
& TTGTGTTGTTTGCCATGAT & & Tsp509l & T & A \\
\hline rs 7794745 & $\begin{array}{l}\text { CAACATTGATCCCTTCAGCCAT } \\
\text { CTCACCAGTGTGCTTCAGACCA }\end{array}$ & 311 & & A & $(78 / 223)$ \\
\hline
\end{tabular}

PCR-RFLP = polymerase chain reaction-restriction fragment length polymorphism; SNP = single nucleotide polymorphism; bp = base pair.

\section{Statistical analysis}

A chi-square test $\left(\chi^{2}\right)$ was applied to compare the overall frequencies of SNP genotypes between ASD individuals and the control group, as well as to verify whether genotype distributions were in Hardy-Weinberg equilibrium. The Fisher exact test was used to detect differences in the distribution of genotypes (recessive model) in both SNPs of the CNTNAP2 gene. Alpha error of $5 \%(P<0.05)$ was considered acceptable. The analysis of the association between genotypes and predisposition to ASD was performed by calculating the odds ratio (OR) with a confidence interval (Cl) of $95 \%$.

\section{RESULTS}

The frequency of the presumed risk allele (T) of SNP rs 7794745 was 0.43 in autistic patients; 43 individuals were homozygous for this polymorphism (TT), and 167 were A carriers (AA $=71$ and $A T=96)$. There was no statistic difference in the frequency of genotypes for this group $\left(\chi^{2}\right.$ $=4.715, \mathrm{P}=0.095$, degree of freedom $=2$ ). In the control group, we found a frequency of 0.38 for the risk allele; 25 individuals were homozygous for this polymorphism (TT), and 175 were A carriers $(\mathrm{AA}=75$ and $\mathrm{AT}=100)$.

Comparative analysis of the distribution of the homozygous genotype for the presumed risk allele (TT) between individuals with ASD and the control group showed a statistically significant difference $(P=0.034)$ between the two groups. In addition, the results suggested an association between this specific genotype and ASD $(\mathrm{OR}=1.802 ; 95 \% \mathrm{Cl}=1.054-3.083 ; \mathrm{P}=0.042)($ Table 2$)$.

\begin{tabular}{|c|c|c|c|c|c|c|}
\hline \multirow[t]{2}{*}{ CNTNAP2 rs 7794745} & ASD $(N=210)$ & Control $(\mathrm{N}=200)$ & $\mathrm{P}^{*}$ & OR & $\mathrm{P}^{* *}$ & $95 \% \mathrm{Cl}$ \\
\hline & {$[\mathrm{N}(\%)]$} & {$[\mathrm{N}(\%)]$} & & & & \\
\hline \multicolumn{7}{|l|}{ Genotypes } \\
\hline $\mathrm{AA}$ & $71(33.8 \%)$ & $75(37.5 \%)$ & 0.470 & 0.852 & 0.498 & $0.568-1.268$ \\
\hline AT & $96(45.7 \%)$ & $100(50.0 \%)$ & 0.429 & 0.842 & 0.442 & $0.571-1.241$ \\
\hline TT & $43(20.5 \%)$ & $25(12.4 \%)$ & 0.034 & 1.802 & 0.042 & $1.054-3.083$ \\
\hline \multicolumn{7}{|l|}{ Alleles } \\
\hline A & $238(56.7 \%)$ & $250(62.5 \%)$ & 0.102 & 0.785 & 0.103 & $0.593-1.038$ \\
\hline $\mathrm{T}$ & $182(43.3 \%)$ & $150(37.5 \%)$ & & & & \\
\hline
\end{tabular}

${ }^{*}$ Calculated by the Fisher exact test. ${ }^{* *}$ Odds ratio. $95 \% \mathrm{Cl}=$ confidence interval.

The frequency of the presumed risk allele (C) of the CNTNAP2 rs2710102 SNP was 0.52 . For this polymorphism, 50 individuals were homozygous (CC), and 160 were T carriers (CT: N 
$=119$ and TT: $N=41)$. In the control group, we found a frequency of 0.58 for the risk allele; 64 individuals were homozygous for this polymorphism (CC), and 136 were T carriers (TT $=32$ and $C T=104)$. The frequencies of the $C$ allele between the control and ASD groups were similar $\left(\chi^{2}=\right.$ 3.449; $P=0.176$; $D F=2$ ), and the distribution of the risk genotype $C C$ was also similar between the two groups $(P=0.077)$. This finding suggests that this allele on the rs2710102 SNP is not associated with $\mathrm{ASD}(\mathrm{OR}=0.664,95 \% \mathrm{Cl}=0.429-1.026, \mathrm{P}=0.082)($ Table 3$)$.

\begin{tabular}{|c|c|c|c|c|c|c|}
\hline CNTNAP2 rs 2710102 & ASD (N = 210) & Control $(\mathrm{N}=200)$ & $\mathrm{P}^{*}$ & OR & $P^{* *}$ & $95 \% \mathrm{Cl}$ \\
\hline & {$[\mathrm{N}(\%)]$} & {$[\mathrm{N}(\%)]$} & & & & \\
\hline \multicolumn{7}{|l|}{ Genotypes } \\
\hline TT & $41(19.5 \%)$ & $32(16 \%)$ & 0.369 & 1.274 & 0.422 & $0.765-2.119$ \\
\hline CT & $119(56.7 \%)$ & $104(52 \%)$ & 0.369 & 1.207 & 0.396 & $0.818-1.781$ \\
\hline $\mathrm{CC}$ & $50(23.8 \%)$ & $64(32 \%)$ & 0.077 & 0.664 & 0.082 & $0.429-1.026$ \\
\hline \multicolumn{7}{|l|}{ Alleles } \\
\hline $\mathrm{C}$ & $219(52.1 \%)$ & $232(58 \%)$ & 0.106 & 0.789 & 0.106 & $0.599-1.040$ \\
\hline$T$ & $201(47.8 \%)$ & $168(42 \%)$ & & & & \\
\hline
\end{tabular}

${ }^{*}$ Calculated by the Fisher exact test. ${ }^{* *}$ Odds ratio. $95 \% \mathrm{Cl}=$ confidence interval.

The rs7794745 and rs2710102 genotypes were found to be in Hardy-Weinberg equilibrium in the control group $\left(\chi^{2}=0.89, P=0.345\right.$ and $\left.\chi^{2}=0.90, P=0.341\right)$. There was no also evidence of linkage disequilibrium $\left(D^{\prime}=0.034\right.$ and $\mathrm{r} 2=0.001$ ) between the SNPs, which are $1 \mathrm{Mb}$ from each other.

\section{DISCUSSION}

Converging evidence suggests that the CNTNAP2 gene is a strong candidate gene for predisposition to autism (Stein et al., 2011; Peñagarikano and Geschwind, 2012; Poot, 2015). Common genomic variants of CNTNAP2 have been associated with autism as well as related phenotypes such as impaired language function, abnormal social behavior, intellectual deficiency, epilepsy, and schizophrenia (Bakkaloglu et al., 2008; Friedman et al., 2008; Betancur, 2011; Miles, 2011; Angelidou et al., 2012).

In this study, we found that the frequency of the T allele of the CNTNAP2 SNP rs779475 in autistic patients (0.43) was similar to the frequency of 0.47 described in the database dbSNP polymorphisms/MAF (MinorAlleleCount) of the National Center for Biotechnology Information (NCBI).

We found significantly higher frequency of the TT genotype of SNP rs7794745 in individuals diagnosed with ASD than in healthy subjects. The presence of the risk allele $T$ in its homozygous form has been associated with altered activation of brain areas responsible for language in non-autistic individuals (Whalley et al., 2011). Language deficits are also core features of ASD. Genetic variations and abnormal gene expression of CNTNAP2 may increase the risks for specific language impairments by altering brain function during linguistic processing, which could result in manifestations such as found in individuals with ASD (Rodenas-Cuadrado et al., 2014). A positive association between the TT genotype and predisposition for autism has been observed by other researchers (Arking et al., 2008; Tan et al., 2010; Poot, 2015). Therefore, based on the results of our study, we suggest that a common variant of CNTNAP2 (genotype TT for rs7794745) can contribute to susceptibility to autism, which is in agreement with previous findings.

Our results showed that the frequency of the $C$ allele (0.52) of the CNTNAP2 SNP rs2710102 in autism was also similar to the frequency described in SNP/MAF, which is 0.60 (NCBI). 
Although some studies have proposed associations between the polymorphism rs2710102 and predisposition to autism (Alarcón et al., 2008; Scott-Van Zeeland et al., 2010), we did not find a significant difference between the frequencies of the CC risk genotype in the autistic and control groups. Similarly, other groups have also reported no association between this genotype and ASD in different populations (Whalley et al., 2011; Sampath et al., 2013). It was concluded that data on association between common variants of the CNTNAP2 gene and ASD have high variability. For example, Peñagarikano and Geschwind (2012) presented a review of more than 10 studies on variants of the CNTNAP2 gene, suggesting a possible association between these genotypes with ASD and other psychiatric disorders. In contrast, Toma et al. (2013) performed a case-control association study involving 322 Spanish autistic patients and 524 controls, which suggested that rs2710102 and rs7794745 are unlikely to contribute to susceptibility to autism.

Ethnic characteristics of populations may result in distinct genetic susceptibility for the same diseases. As a result of five centuries of cross-breeding between Amerindians, Europeans, and Africans, the Brazilian population displays very high levels of genomic diversity, with a predominant European ancestry in different regions (Pena et al., 2011; Huguet et al., 2013) as the one studied here (São Paulo State). Thus, the genetic heterogeneity and admixture of Brazilians may have important implications in studies of genetic markers, including SNPs (Lee et al., 2013). Analysis of susceptibilities to complex diseases such as ASD may require different genetic markers for different populations, which can be important in the practice of clinical genetics and the etiology of these diseases.

The contribution of genes and their SNPs to complex diseases is still an open question. Moreover, the frequency of individual alleles is influenced by the sizes in the study groups (Murdoch and State, 2013). Therefore, future studies should aim to include clinical details of patient samples, which may clarify the significance of these SNPs for the risk of autism.

Therefore, the TT genotype (rs7794745) of the CNTNAP2 gene may be associated with predisposition to autism in the Brazilian population. We suggest that it can at least increase the risk for ASD, considering that SNPs in complex diseases generally have combined effects.

\section{Conflicts of interest}

The authors declare no conflict of interest.

\section{ACKNOWLEDGMENTS}

Research supported by Coordenação de Aperfeiçoamento de Pessoal de Nível Superior (CAPES) and BAP/FAMERP (Grant \#2013/2014). The authors would like to acknowledge all the participants of this study and their families.

\section{REFERENCES}

Abrahams BS and Geschwind DH (2008). Advances in autism genetics: on the threshold of a new neurobiology. Nat. Rev. Genet. 9: 341-355.http://dx.doi.org/10.1038/nrg2346

Alarcón M, Abrahams BS, Stone JL, Duvall JA, et al. (2008). Linkage, association, and gene-expression analyses identify CNTNAP2 as an autism-susceptibility gene. Am. J. Hum. Genet. 82: 150-159.http://dx.doi.org/10.1016/j.ajhg.2007.09.005

Angelidou A, Asadi S, Alysandratos KD, Karagkouni A, et al. (2012). Perinatal stress, brain inflammation and risk of autismreview and proposal. BMC Pediatr. 12: 89.http://dx.doi.org/10.1186/1471-2431-12-89 
APA (American Psychiatric Association). (2013) Autism Spectrum Disorder. In: Diagnostic and Statistical Manual of Mental Disorders. 5th edn. Available at [http://www.dsm5.org/Pages/Default.aspx]. Accessed August 8, 2015.

Arking DE, Cutler DJ, Brune CW, Teslovich TM, et al. (2008). A common genetic variant in the neurexin superfamily member CNTNAP2 increases familial risk of autism. Am. J. Hum. Genet. 82: 160-164.http://dx.doi.org/10.1016/j.ajhg.2007.09.015

Bakkaloglu B, O'Roak BJ, Louvi A, Gupta AR, et al. (2008). Molecular cytogenetic analysis and resequencing of contactin associated protein-like 2 in autism spectrum disorders. Am. J. Hum. Genet. 82: 165-173.http://dx.doi.org/10.1016/j. ajhg.2007.09.017

Betancur C (2011). Etiological heterogeneity in autism spectrum disorders: more than 100 genetic and genomic disorders and still counting. Brain Res. 1380: 42-77.http://dx.doi.org/10.1016/j.brainres.2010.11.078

Buxbaum JD, Bolshakova N, Brownfeld JM, Anney RJ, et al. (2014). The Autism Simplex Collection: an international, expertly phenotyped autism sample for genetic and phenotypic analyses. Mol. Autism 5: 34.http://dx.doi.org/10.1186/2040-2392$\underline{5-34}$

Chung BHY, Tao VQ and Tso WW (2014). Copy number variation and autism: new insights and clinical implications. J. Formos. Med. Assoc. 113: 400-408.http://dx.doi.org/10.1016/j.jfma.2013.01.005

Clemm von Hohenberg C, Wigand MC, Kubicki M, Leicht G, et al. (2013). CNTNAP2 polymorphisms and structural brain connectivity: a diffusion-tensor imaging study. J. Psychiatr. Res. 47: 1349-1356.http://dx.doi.org/10.1016/j. jpsychires.2013.07.002

Currenti SA (2010). Understanding and determining the etiology of autism. Cell. Mol. Neurobiol. 30: 161-171.http://dx.doi. org/10.1007/s10571-009-9453-8

Devlin B and Scherer SW (2012). Genetic architecture in autism spectrum disorder. Curr. Opin. Genet. Dev. 22: 229-237.http:// dx.doi.org/10.1016/j.gde.2012.03.002

Faras H, Al Ateeqi N and Tidmarsh L (2010). Autism spectrum disorders. Ann. Saudi Med. 30: 295-300.http://dx.doi. org/10.4103/0256-4947.65261

Friedman JI, Vrijenhoek T, Markx S, Janssen IM, et al. (2008). CNTNAP2 gene dosage variation is associated with schizophrenia and epilepsy. Mol. Psychiatry 13: 261-266.http://dx.doi.org/10.1038/sj.mp.4002049

Huguet G, Ey E and Bourgeron T (2013). The genetic landscapes of autism spectrum disorders. Annu. Rev. Genomics Hum. Genet. 14: 191-213.http://dx.doi.org/10.1146/annurev-genom-091212-153431

Jonsson L, Zettergren A, Pettersson E, Hovey D, et al. (2014). Association study between autistic-like traits and polymorphisms in the autism candidate regions RELN, CNTNAP2, SHANK3, and CDH9/10. Mol. Autism 5: 55.http://dx.doi. org/10.1186/2040-2392-5-55

Lai MC, Lombardo MV and Baron-Cohen S (2014). Autism. Lancet 383: 896-910.http://dx.doi.org/10.1016/S0140$\underline{6736(13) 61539-1}$

Lauritsen MB (2013). Autism spectrum disorders. Eur. Child Adolesc. Psychiatry 22 (Suppl 1): 37-42.http://dx.doi.org/10.1007/ $\underline{\mathrm{s} 00787-012-0359-5}$

Lee SH, Ripke S, Neale BM, Faraone SV, et al.; Cross-Disorder Group of the Psychiatric Genomics Consortium; International Inflammatory Bowel Disease Genetics Consortium (IIBDGC) (2013). Genetic relationship between five psychiatric disorders estimated from genome-wide SNPs. Nat. Genet. 45: 984-994.http://dx.doi.org/10.1038/ng.2711

Li X, Hu Z, He Y, Xiong Z, et al. (2010). Association analysis of CNTNAP2 polymorphisms with autism in the Chinese Han population. Psychiatr. Genet. 20: 113-117.

Loke YJ, Hannan AJ and Craig JM (2015). The role of epigenetic change in autism spectrum disorders. Front. Neurol. 6: 107. http://dx.doi.org/10.3389/fneur.2015.00107

Mefford HC, Batshaw ML and Hoffman EP (2012). Genomics, intellectual disability, and autism. N. Engl. J. Med. $366: 733-743$. http://dx.doi.org/10.1056/NEJMra1114194

Miles JH (2011). Autism spectrum disorders--a genetics review. Genet. Med. 13: 278-294.http://dx.doi.org/10.1097/ GIM.0b013e3181ff67ba

Miller SA, Dykes DD and Polesky HF (1988). A simple salting out procedure for extracting DNA from human nucleated cells. Nucleic Acids Res. 16: 1215.http://dx.doi.org/10.1093/nar/16.3.1215

Murdoch JD and State MW (2013). Recent developments in the genetics of autism spectrum disorders. Curr. Opin. Genet. Dev. 23: 310-315.http://dx.doi.org/10.1016/j.gde.2013.02.003

Pena SD, Di Pietro G, Fuchshuber-Moraes M, Genro JP, et al. (2011). The genomic ancestry of individuals from different geographical regions of Brazil is more uniform than expected. PLoS One 6: e17063.http://dx.doi.org/10.1371/journal. pone.0017063

Peñagarikano O and Geschwind DH (2012). What does CNTNAP2 reveal about autism spectrum disorder? Trends Mol. Med. 18: 156-163.http://dx.doi.org/10.1016/j.molmed.2012.01.003

Perche O, Laumonnier F, Baala L, Ardourel MY, et al. (2010). Autism, genetics and synaptic function alterations. Pathol. Biol. 
(Paris) 58: 381-386.http://dx.doi.org/10.1016/j.patbio.2009.12.005

Poot M (2015). Connecting the CNTNAP2 networks with neurodevelopmental disorders. Mol. Syndromol. 6: 7-22.http://dx.doi. org/10.1159/000371594

Rodenas-Cuadrado P, Ho J and Vernes SC (2014). Shining a light on CNTNAP2: complex functions to complex disorders. Eur. J. Hum. Genet. 22: 171-178.http://dx.doi.org/10.1038/ejhg.2013.100

Sampath S, Bhat S, Gupta S, O'Connor A, et al. (2013). Defining the contribution of CNTNAP2 to autism susceptibility. PLoS One 8: e77906.http://dx.doi.org/10.1371/journal.pone.0077906

Scott-Van Zeeland AA, Abrahams BS, Alvarez-Retuerto AI, Sonnenblick LI, et al. (2010). Altered functional connectivity in frontal lobe circuits is associated with variation in the autism risk gene CNTNAP2. Sci. Transl. Med. 2: 56ra80.http:/l dx.doi.org/10.1126/scitransImed.3001344

Sokolowsky M, Fakra E and Azorin JM (2012). Endophenotypes and autism spectrum disorders. Encephale 38 (Suppl 3): S67-S69.http://dx.doi.org/10.1016/S0013-7006(12)70080-5

Stein MB, Yang BZ, Chavira DA, Hitchcock CA, et al. (2011). A common genetic variant in the neurexin superfamily member CNTNAP2 is associated with increased risk for selective mutism and social anxiety-related traits. Biol. Psychiatry 69: 825-831.http://dx.doi.org/10.1016/j.biopsych.2010.11.008

Tan GC, Doke TF, Ashburner J, Wood NW, et al. (2010). Normal variation in fronto-occipital circuitry and cerebellar structure with an autism-associated polymorphism of CNTNAP2. Neuroimage 53: 1030-1042.http://dx.doi.org/10.1016/j. neuroimage.2010.02.018

Toma C, Hervás A, Torrico B, Balmaña N, et al. (2013). Analysis of two language-related genes in autism: a case-control association study of FOXP2 and CNTNAP2. Psychiatr. Genet. 23: 82-85.http://dx.doi.org/10.1097/YPG.0b013e32835d6fc6

Whalley HC, O'Connell G, Sussmann JE, Peel A, et al. (2011). Genetic variation in CNTNAP2 alters brain function during linguistic processing in healthy individuals. Am. J. Med. Genet. B. Neuropsychiatr. Genet. 156: 941-948.http://dx.doi. org/10.1002/ajmg.b.31241

Ye H, Liu J and Wu JY (2010). Cell adhesion molecules and their involvement in autism spectrum disorder. Neurosignals 18: 62-71.http://dx.doi.org/10.1159/000322543 